\title{
The Adsorption Properties of Modified Soda Lime for Carbon Dioxide Removal within Closed Environment of Coal Mine Refuge Chamber
}

\author{
Wen-mei Gai ${ }^{\mathrm{a}, \mathrm{b}}$, Yun-feng Deng ${ }^{\mathrm{b}}$, Yan Du ${ }^{\mathrm{a},{ }^{*}}$ \\ a-School of Civil and Environmental Engineering, University of Science and \\ Technology Beijing, Beijing 100083,China \\ b-Chinese Academy of Governance, Beijing 100089, China
}

E-mail addresses: mcgrady2006duyan@126.com; Tel.: +0086 13426214037. 


\section{The Introduction of Multi-Index Orthogonal Experiment (MOE) Method}

The Multi-Index Orthogonal Experiment (MOE) method is regarded as a modern approach to characterize and optimize system performance in many research areas. In general, practical engineering design and optimization usually involve three or more influential parameters, which requires full factorial design analysis. For a full factorial experiment of this study with 3 influential parameters (factors) and at 3 levels, the number of necessary trials would be $3^{3}=27$. Such a large number of experiments are difficult and expensive to carry out, therefore, as an alternative, the MOE method can be used to select representative points from the full factorial experiment in such a way that the points are distributed uniformly within the test range and thus can adequately represent the overall situation. The orthogonal array (a subset of the full factorial array with 27 experiments) is described as $\mathrm{La}\left(\mathrm{b}^{\mathrm{c}}\right)$, where $\mathrm{L}$ is the symbol of orthogonal design, and a is the number of experimental runs, $b$ the number of levels and $\mathrm{c}$ the number of factors.

The MOE method replaces the full factorial experiment $\left(3^{4}=27\right)$ with a lean, less expensive, faster, partial factorial experiment (9 experiments for the L9 $\left(3^{4}\right)$ ) [48]. The MOE method for the partial factorial experiment is based on specially developed orthogonal arrays. Since the partial experiment is only a sample of the full experiment, its analysis must include an analysis of the confidence that can be placed in the results. This paper does not present the calculation processes of mean and range, the details of which can be found in. The results of the MOE calculations are summarized in Table 6 and Table 7 for the selected 18 experiments. Two matrices with calculated Ki and $\mathrm{R}$ values are shown. The top matrix of $\mathrm{Ki}$ data is obtained by the sum of adsorption rate data. For example, the $\mathrm{K}_{1}=30.1$ value in Table 6 for Factor $\mathrm{A}$ is obtained by adding all adsorption rate values for which Factor $\mathrm{A}=1$ :

$$
\overline{\mathrm{K}}_{1}=8.4+10.2+11.5=30.1(7)
$$

To find the $\mathrm{R}$ values, the maximum and minimum $\mathrm{K}$ value is found for each of the 6 influential factors. The $\mathrm{R}$ value for each factor is calculated by finding differences between maximum and minimum values (shown within the boxes in Table 4). For example, for Factor $A: R=33.4-30.1=3.3$. Based on $\mathrm{R}$ values, the remaining factors were ordered by significance, and the order is shown in Table 6, the larger the 
$\mathrm{R}$ value for a factor, the stronger is the influence of the test factor on the result.

Table S1.L ${ }_{9}\left(3^{4}\right)$ Standard Orthogonal Experiment Plan for Soda Lime of Different Composition

\begin{tabular}{c|c|c|c|c}
\hline \multirow{2}{*}{ Soda lime NO. } & $\begin{array}{c}\mathrm{A} \mathrm{Al}_{2} \mathrm{O}_{3} \text { mass } \\
\text { fraction }(w / \%)\end{array}$ & $\begin{array}{c}\mathrm{B} \mathrm{H}_{2} \mathrm{O} \text { mass } \\
\text { fraction }(\mathrm{w} / \%)\end{array}$ & $\begin{array}{c}\mathrm{C} \mathrm{NaOH} \text { mass } \\
\text { fraction }(w / \%)\end{array}$ & \multirow{2}{*}{ Level } \\
\cline { 2 - 4 } & 1 & 2 & 3 & 1 \\
\hline $\mathrm{S}-1$ & $1(4 \%)$ & $1(9 \%)$ & $1(4 \%)$ & 2 \\
\hline $\mathrm{S}-2$ & $1(4 \%)$ & $2(12 \%)$ & $2(5 \%)$ & 3 \\
\hline $\mathrm{S}-3$ & $1(4 \%)$ & $3(15 \%)$ & $3(6 \%)$ & 3 \\
\hline $\mathrm{S}-4$ & $2(6 \%)$ & $1(9 \%)$ & $2(5 \%)$ & 1 \\
\hline $\mathrm{S}-5$ & $2(6 \%)$ & $2(12 \%)$ & $3(6 \%)$ & 2 \\
\hline $\mathrm{S}-6$ & $2(6 \%)$ & $3(15 \%)$ & $1(4 \%)$ & 2 \\
\hline $\mathrm{S}-7$ & $3(8 \%)$ & $1(9 \%)$ & $3(6 \%)$ & 3 \\
\hline $\mathrm{S}-8$ & $3(8 \%)$ & $2(12 \%)$ & $1(4 \%)$ & 1 \\
\hline $\mathrm{S}-9$ & $3(8 \%)$ & $3(15 \%)$ & $2(5 \%)$ & \\
\hline
\end{tabular}

Table S2. $\mathrm{L}_{9}\left(3^{4}\right)$ Standard Orthogonal Experiment Plan for Soda Lime in Different Working Modes

\begin{tabular}{c|c|c|c|c}
\hline $\begin{array}{c}\text { Working modes } \\
\text { NO. }\end{array}$ & $\begin{array}{c}\text { D the type of } \\
\text { soda lime (NO.) }\end{array}$ & $\begin{array}{c}\text { E thickness of } \\
\text { soda lime }(\mathrm{cm})\end{array}$ & F fan power (W) & \multirow{2}{*}{ Level } \\
\cline { 2 - 4 } & 1 & 2 & 3 & \\
\hline W-1 & $1(\mathrm{~S}-5)$ & $1(6 \mathrm{~cm})$ & $1(20 \mathrm{~W})$ & 1 \\
\hline W-2 & $1(\mathrm{~S}-5)$ & $2(8 \mathrm{~cm})$ & $2(25 \mathrm{~W})$ & 2 \\
\hline W-3 & $1(\mathrm{~S}-5)$ & $3(10 \mathrm{~cm})$ & $3(30 \mathrm{~W})$ & 3 \\
\hline W-4 & $2(\mathrm{~S}-6)$ & $1(6 \mathrm{~cm})$ & $2(25 \mathrm{~W})$ & 3 \\
\hline W-5 & $2(\mathrm{~S}-6)$ & $2(8 \mathrm{~cm})$ & $3(30 \mathrm{~W})$ & 1 \\
\hline W-6 & $2(\mathrm{~S}-6)$ & $3(10 \mathrm{~cm})$ & $1(20 \mathrm{~W})$ & 2 \\
\hline W-7 & $3(\mathrm{~S}-7)$ & $1(6 \mathrm{~cm})$ & $3(30 \mathrm{~W})$ & 2 \\
\hline W-8 & $3(\mathrm{~S}-7)$ & $2(8 \mathrm{~cm})$ & $1(20 \mathrm{~W})$ & 3 \\
\hline W-9 & $3(\mathrm{~S}-7)$ & $3(10 \mathrm{~cm})$ & $2(25 \mathrm{~W})$ & 1 \\
\hline
\end{tabular}


Table S3. L9 $\left(3^{4}\right)$ Standard Orthogonal Experiment Result and Analysis for Soda Lime of Different Composition

\begin{tabular}{|c|c|c|c|c|}
\hline Soda lime NO. & $\begin{array}{l}\mathrm{A} \mathrm{Al}_{2} \mathrm{O}_{3} \text { mass } \\
\text { fraction }(\mathrm{w} / \%)\end{array}$ & $\begin{array}{c}\mathrm{B} \mathrm{H}_{2} \mathrm{O} \text { mass } \\
\text { fraction }(\mathrm{w} / \%)\end{array}$ & $\begin{array}{l}\mathrm{C} \mathrm{NaOH} \text { mass } \\
\text { fraction }(\mathrm{w} / \%)\end{array}$ & $\begin{array}{c}\text { Adsorption rate } \\
(\mathrm{L} / \mathrm{min})\end{array}$ \\
\hline S1 & 4 & 9 & 4 & 8.4 \\
\hline $\mathrm{S} 2$ & 4 & 12 & 5 & 10.2 \\
\hline S3 & 4 & 15 & 6 & 11.5 \\
\hline $\mathrm{S} 4$ & 6 & 9 & 5 & 9.6 \\
\hline S5 & 6 & 12 & 6 & 12.3 \\
\hline S6 & 6 & 15 & 4 & 10.8 \\
\hline $\mathrm{S} 7$ & 8 & 9 & 6 & 12.6 \\
\hline S8 & 8 & 12 & 4 & 9.1 \\
\hline S9 & 8 & 15 & 5 & 11.7 \\
\hline$\overline{\mathrm{K}}_{1}$ & 30.1 & 30.6 & 28.3 & \multirow{4}{*}{$\mathrm{T}=96.2$} \\
\hline$\overline{\mathrm{K}}_{2}$ & 32.7 & 31.6 & 31.5 & \\
\hline$\overline{\mathrm{K}}_{3}$ & 33.4 & 34 & 36.4 & \\
\hline $\mathrm{R}$ & 3.3 & 3.4 & 8.1 & \\
\hline Better level & 7 & 6.2 & 3 & \\
\hline Order of factors & III & II & I & \\
\hline
\end{tabular}

Table S4. $\mathrm{L}_{9}\left(3^{4}\right)$ Standard Orthogonal Experiment Result and Analysis for Soda Lime in 


\section{Different Working Modes}

\begin{tabular}{|c|c|c|c|c|}
\hline $\begin{array}{c}\text { Working } \\
\text { condition NO. }\end{array}$ & $\begin{array}{c}\text { D the type of } \\
\text { soda lime (NO.) }\end{array}$ & $\begin{array}{l}\text { E thickness of } \\
\text { soda lime }(\mathrm{cm})\end{array}$ & $\mathrm{F}$ fan $\operatorname{power}(\mathrm{W})$ & $\begin{array}{l}\text { Adsorption } \\
\operatorname{rate}(\mathrm{L} / \mathrm{min})\end{array}$ \\
\hline $\mathrm{W}-1$ & 5 & 6 & 20 & 8.7 \\
\hline $\mathrm{W}-2$ & 5 & 8 & 25 & 14.2 \\
\hline W-3 & 5 & 10 & 30 & 14.7 \\
\hline W-4 & 6 & 6 & 25 & 8.6 \\
\hline W-5 & 6 & 8 & 30 & 14.0 \\
\hline W-6 & 6 & 10 & 20 & 6.8 \\
\hline W-7 & 7 & 6 & 30 & 14.3 \\
\hline W-8 & 7 & 8 & 20 & 6.7 \\
\hline W-9 & 7 & 10 & 25 & 11.6 \\
\hline$\overline{\mathrm{K}}_{1}$ & 37.6 & 31.6 & 22.2 & \multirow{4}{*}{$\mathrm{T}=99.6$} \\
\hline$\overline{\mathrm{K}}_{2}$ & 29.4 & 34.9 & 34.4 & \\
\hline$\overline{\mathrm{K}}_{3}$ & 32.6 & 33.1 & 43 & \\
\hline $\mathrm{R}$ & 8.2 & 3.3 & 20.8 & \\
\hline Better level & 5 & 8 & 30 & \\
\hline Order of factors & II & III & I & \\
\hline
\end{tabular}

